\title{
出入港時の要素操船性能について一 II.
}

\section{——保針操船とその限界——}

\author{
小 瀬 邦 治*・岩 崎 寛 希**・吉 川 賢 治*** \\ Elemental Performances of Harbour Approaching and Departing Maneuvers-II. \\ -Manual Course-Keeping and Allowable Limit of Directional Instability of Ships
}

Kuniji KOSE, Hiroki IWASAKI and Kenji YOSHIKAWA

\begin{abstract}
In the previous report, the authors have pointed out that manoeuvring motions of ships in harbours can be briefly divided into and composed of several kinds of elemental manoeuvres, such as course keeping and changing with/without speed changing, turning drifting and so on. In the present report, an attempt is done to analyze a manual steering system of directionally unstable ships under speed changing, putting a special emphasis on the allowable limit of instability.

At first, the frequency responses of unstable ships are examined and the specific characteristics of phase lag of unstable ships are pointed out. Summarizing in short, the directional stability and the rudder effectiveness of ships under decelerating become less but the phase lag of ships under the condition is not so different from the one under constant speed.

Secondly, the performances of human operators are investigated by the manoeuvring simulator of Hiroshima university and their models are identified statistically from manual course-keeping simulations under constant advance speed. It is pointed out from such studies that human operators can adjust easily their control gain, responding to the properties of ships but they have a limit in compensating the phase lag of unstable ships for stabilizing the manual course-keeping system. The allowable limit of the phase lag to be compensated by human operators is roughly estimated about 30 to 50 degrees. Then, the difficulty of manual course-keeping for such ships is characterized by the phase lag to be compensated by human operators. Taking the above into consideration, it is concluded that the difficulty of course-keeping under decelerating differs little from under constant speed.

The above conclusion is finally made sure of from manual course-keeping simulations under decelerating.
\end{abstract}

\section{1.は じめに}

IMO は航行安全の立場から, 船に要求される最少限度の操緃性能（操縦性基準）のあり方を検討しているが, これには最も安全性が重要となる出入港操船を考慮する必要がある。又, 船の操縱性能を記載した Maneuverability Booklet の検討の際, 操船者側からそれに盛りこんで欲しいと要請のあった項目(1)の主力は港湾域にお

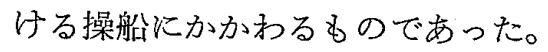

\footnotetext{
* 正 会 員 広島大学工学部 (T724 東広島市西条町大字下見)

** 正 会 員 大島商船高等専門学校 (T742-21 山口県大島郡大島町小松 1091-1)

*** 学生会員 広島大学工学部 ( 7724 東広島市西条町大字下見)
} 
船の操縱性に関する研究の進展に伴って，操縦運動の数学モデルは一般の航行局面に対しては実用の域に達 し(2)，水域に制限があり，低速で縦横自在に操船される局面に対しても検討 ${ }^{(3)}$ が進んでいる。これらを利用して， 定常旋回特性とか Z 試験成績とか，代表的な操縦運動はほぼ推定できる状態になっている。

こうして, 確立しつつある操縦運動の数学モデルを活用して, 港湾域に和ける操船の安全に資することが今日 の操縦性研究の課題の一つとなる。先に筆者らは, 出入港操船を加減速を伴いつつ保針, 变針する, その場回頭 する, そして横移動するといった要素操船の組合わせで考劣ることを提案した(4)。そうすると, 各要素操船の性 能とか, 制御限界といった問題は, 運動力学的, 制御工学的立場から取扱いらることになる。さらに, 操縦性能 基準のあり方を考える祭にも，要素操船といら単純な操縱が人間の能力で実現できるかといら立場を当面の出発 点とすることができる。

そこで本稿に特いては，加速，減速しつつ保針する要素操船を取りあげ，操縦性能の拉よそ明確となった船と， 特性の明瞭でない操舵員の 2 者から成る閉ループ制御系の安定性という立場から, 人間の制御限界, 船に要求さ れるべき性能等について考察し，実時間操船シミュレータを用いて確認したので報告する。

\section{2. 供試船と減速中の操縦性能}

2. 1 供試船シリーズ

この研究に用いる供試船としては，強い針路不安定な性能を持つものが望ましい。そこで初期に建造された典 型的なVL C Cの中から，不安定ループの全幅が $10^{\circ}$ 以上のV L C Cで，拘束操翊性試験が実施されているもの を選択した。

変速中の操縦運動性能を正確に推定するには，プロペラ回転数の変化が舵の特性に及ぼす影響を正確に見積る 必要があり，船体，プロペラ，舵の

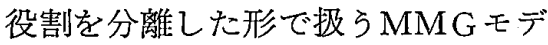
ルを用いて流体力を記述するのが望 ましい(5)。しかし，拘束操縦性試験 は実施されているが，プロペラと舵 に作用する流体力の計湘はなされて いないので, プロペラ特性, 舵の船 体に対する干渉係数等を実績から推 定し，MMGモデルの諸係数を求め た。この供試船の流力微係数等を表 1 に示す。又, 無次元化の方法等は

I T T Cの標準によった。

船の大きさが変わると, 操縦運動 のテンポが変化する。人間の特性は この運動のテンポによって変わるこ とが知られているから，供試船とし て, 母型の Lpp $=310 \mathrm{~m}$ のV L C C の他に，船長が， $200 \mathrm{~m}, 100 \mathrm{~m}, 50 \mathrm{~m}$ 表 1 供試モデル (母型) の流力微係数

\begin{tabular}{|c|c|c|c|c|c|}
\hline 微係数 & $* 10^{3}$ & 微係数 & $* 10^{3}$ & 微䃄数 & $* 10$ \\
\hline $\mathrm{Js}$ & 689.45 & $Y^{\prime} \dot{v}$ & -12.21 & $N^{\prime} i$ & -0.47 \\
\hline $\mathrm{m}^{\prime}$ & 13.794 & $Y^{\prime} \dot{r}$ & -0.612 & $N^{\prime} \dot{r}$ & -0.677 \\
\hline$I^{\prime} z Z$ & 0.849 & $Y^{\prime} v$ & -12.377 & $N^{\prime} v$ & -7.5622 \\
\hline & & $Y^{\prime} r$ & 2.5008 & $N^{\prime} r$ & -2.0425 \\
\hline$x^{\prime} \dot{u}$ & -0.84 & $Y^{\prime} v v v$ & -138.21 & $N^{\prime}$ vuv & 8.1391 \\
\hline$X^{\prime}$ 'us & -0.9725 & $Y^{\prime} r \mathrm{rr}$ & 0.8046 & $\mathrm{~N}^{\prime}$ r $\mathrm{rr}$ & -1.1881 \\
\hline$X^{\prime} v$ & -3.2958 & $Y^{\prime}$ vrr & -21.74 & $N^{\prime} v r r$ & 3.2248 \\
\hline$x^{\prime} v v$ & 8.189 & Y'vvr & 11.066 & $N^{\prime} v v r$ & -13.339 \\
\hline$X^{\prime} v v v$ & 0.0 & & & & \\
\hline$X^{\prime} r r$ & 0.0 & & & & \\
\hline$X^{\prime} v r+Y^{\prime} \dot{v}$ & 10.71 & & & & \\
\hline
\end{tabular}

のものを考えることとした。この換算に拉いて，船体抵抗のみに尺度影響を考慮し，その他の無次元化されたパ ラメタはすべて同じ值を用いている。又，これら４船の舵高さを一定として，舵面積を増減したと仮定して，不 安定ループの全幅が， $15^{\circ} ， 10^{\circ}, 7.5^{\circ}, 5^{\circ}$ の全16隻のシリーズモデルを用意した。図 1 に長さが母型の $310 \mathrm{~m} シ$ リーズの定常旋回特性を示す。

2. 2 針路不安定船の保針時の周波数特性

一定速度で保針航行中，運動が微少であると仮定すれば，重心に原点を置く船体固定座標系を用いて，船の運 動方程式は次式で与えられる。 


$$
\begin{aligned}
& m(\dot{u}-v r)=\frac{\rho}{2} L^{2} U^{2} X^{\prime} \\
& m(\dot{v}+u r)=-\frac{\rho}{2} L^{2} U^{2} Y^{\prime} \\
& I_{Z Z} \dot{r}=\frac{\rho}{2} L^{3} U^{2} N^{\prime}
\end{aligned}
$$

ただし，

$m$ : 質量 $U$ : 船速 $I_{Z Z}:$ 慣性モーメント $X^{\prime}, Y^{\prime}:$ 船に作用する綎横方向の力 $N^{\prime}$ : 船に作用する重心まわりのモーメント $u, v, r$ : 船の縦横方向の速度と旋回角速度

ここで，操舵に対する旋回や横流れは 第 $2 ， 3$ 式を連立した形で考えることが できる。又，保針中であるから旋回と横 流れが微少であると仮定すると，船に作 用する横方向の流体力と重心回りのモー メントは船体とプロペラによって生じる 成分と舵の寄与する成分の和として，次 式で表現できる。

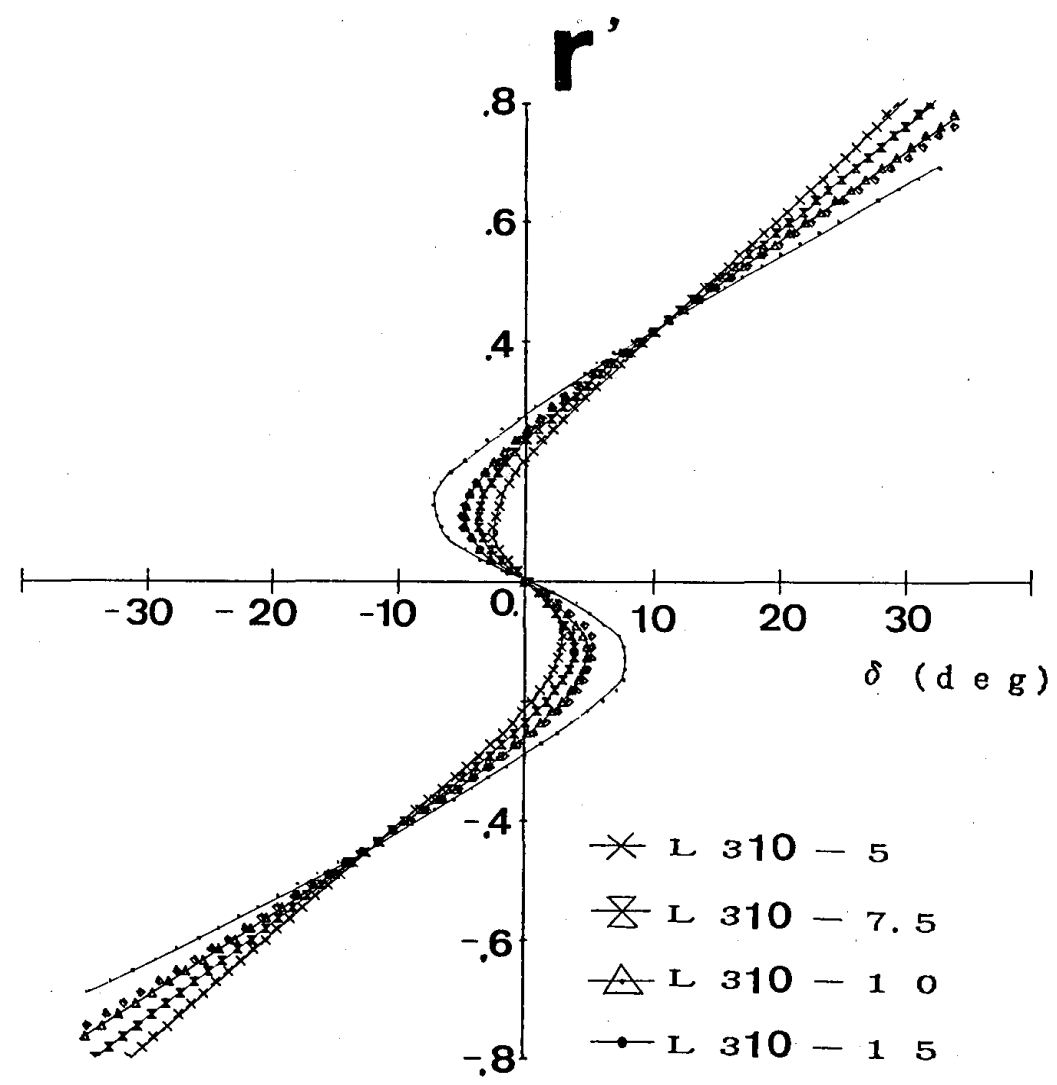

図1日船長 $310 \mathrm{~m}$ の供試シリーズによる定常旋回特性

$$
\begin{aligned}
& Y^{\prime}=\left(Y^{\prime}{ }_{H P} \dot{v} \dot{v}^{\prime}+Y^{\prime}{ }_{H p \dot{r}} \dot{r}^{\prime}\right)+Y_{H P v}^{\prime} v^{\prime}+\left(Y^{\prime}{ }_{H P r}+Y^{\prime} H P \dot{i}\right) r^{\prime}-\left(1+a_{H}\right) F_{N}^{\prime} \cdot \cos \delta \\
& N^{\prime}=\left(N^{\prime}{ }_{H P} \dot{v} \dot{v}^{\prime}+N^{\prime}{ }_{H P \dot{r}} \dot{r}^{\prime}\right)+N_{H}^{\prime}{ }_{H} v v^{\prime}+N^{\prime}{ }_{H P r} \gamma^{\prime}-\left(x_{H}^{\prime}+a_{I I} x_{H}^{\prime}\right) F_{N}^{\prime} \cdot \cos \delta
\end{aligned}
$$

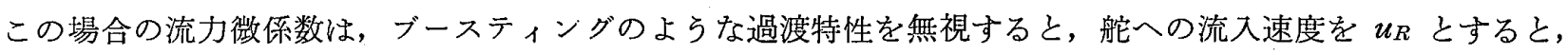
次のように計算できる。

$$
\begin{aligned}
& Y v^{\prime}=Y H P v^{\prime}+k_{1} \gamma_{R}\left(u_{R} / U\right) \\
& Y r^{\prime}=Y H P r^{\prime}+k_{1} \gamma_{R} l_{R}^{\prime}\left(u_{R} / U\right) \\
& N v^{\prime}=N H P v^{\prime}+k_{1} \gamma_{R}\left(u_{R} / U\right) \\
& N r^{\prime}=N H P r^{\prime}+k_{1} \gamma_{R} l_{R}^{\prime}\left(u_{R} / U\right) \\
& Y_{\dot{c}}^{\prime}=k_{1}\left(u_{R} / U\right)^{2} \\
& N_{\dot{c}}^{\prime}=k_{2}\left(u_{R} / U\right)^{2}
\end{aligned}
$$

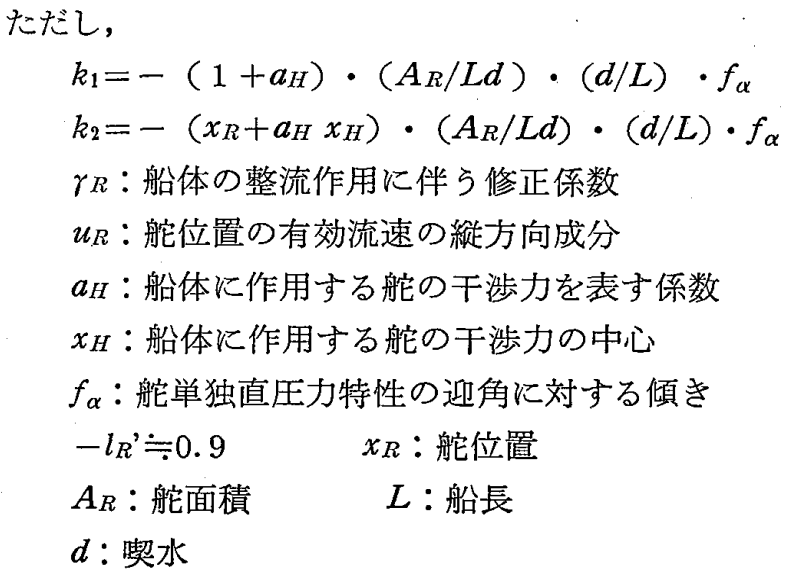

この運動方程式中から横流れの項を消去すると，よく知られた操舵角 $\delta$ による回頭運動を与える応答方程式が 得られる。 


$$
T_{1} T_{2} \ddot{r}+\left(T_{1}+T_{2}\right) \dot{r}+r=K \delta+K T_{3} \dot{\delta}
$$

ただし，

$$
\begin{aligned}
T_{1} T_{2} & =(L / U)^{2} q_{1}{ }_{1} / q^{\prime}{ }_{3} \\
T_{1}+T_{2} & =(L / U) q^{\prime}{ }_{2} / q^{\prime}{ }_{3} \\
K & =(U / L) q^{\prime}{ }_{4} / q^{\prime}{ }_{3} \\
T_{3} & =(L / U) q^{\prime}{ }_{5} / q^{\prime}{ }_{4} \\
q^{\prime}{ }_{1} & =\left(m^{\prime}+m^{\prime}{ }_{y}\right)\left(I^{\prime}{ }_{z z}+J_{z z}^{\prime}\right) \\
q^{\prime}{ }_{2} & =-\left(m^{\prime}+m^{\prime}{ }_{y}\right) N^{\prime} r-Y^{\prime} v\left(I_{z z}+J_{z z}^{\prime}\right) \\
q^{\prime}{ }_{3} & =Y^{\prime}{ }_{v} N^{\prime}{ }_{r}+N^{\prime}{ }_{v}\left\{\left(m^{\prime}+m_{x}\right)-Y^{\prime}{ }_{r}\right\} \\
q^{\prime}{ }_{4} & =N^{\prime}{ }_{v} Y^{\prime}{ }_{\delta}-N^{\prime}{ }_{\delta} Y^{\prime} v \\
q_{5} & =\left(m^{\prime}+m^{\prime}{ }_{y}\right) N^{\prime}{ }_{\delta}
\end{aligned}
$$

$m_{x}, m_{y}: x, y$ 方向の付加質量

$J_{z z}:$ 付加慣性モーメント

$Y_{v}, Y_{r}, N_{v}, N_{r}, Y_{\delta}, N_{\delta}:$ 流力微係数

$r$ : 回頭角速度 $\delta:$ 舵角

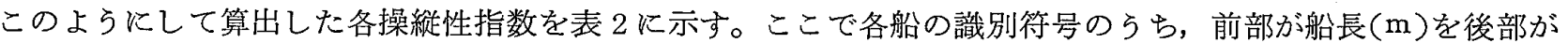
不安定ループの全幅 (度) を示している。又, 各操縦性指数の中で， $K, T_{1}$ と不安定ループ幅の関係を図 2 の実 線で示す。図 1 の旋回特性の不安定ループ幅に直接寄与し, 原点付近の傾斜を与号るKは, 針路不安定船では負 の值を取り，ループ幅によって大きく変化する。又， $T_{1}$ についても同様に負となり，針路安定性によって変わ る。しかし，他の指数 $T_{2}, T_{3}$ については，ほとんどループ幅に依存しないことがわかる。この理由については 後に簡単に考察する。

さてここで，保針時の制御系の周波数特性について考える。一般に船の針路制御系忹図 3 亿示寸構成を持つ。 制御系を構成する要素のらち,コントローラが人間の場合がこの研究の課題である。この閉ループ制御系のうち, 人間以外の操舵機，船，コンパスつまり，制御対象の応答特性は，次式で記述される。

$H G(j \omega)$

$$
=\frac{K\left(1+j \omega T_{3}\right)}{j \omega\left(1+j \omega T_{1}\right)\left(1+j \omega T_{2}\right)\left(1+j \omega T_{E}\right)}
$$

ただし， $T_{E}$ は操舵機の時定数である。

上式を用いて針路不安定な供試船シリーズの船 と操舵機, コンパスの周波数特性を計算した結果 を図 4 に示す。(a)はループ幅 $10^{\circ}$ の母型のもの で，船長を変えた場合を示す。そして（b ) L Lp

\begin{tabular}{|c|c|c|c|c|c|c|c|c|}
\hline Ship & $\mathrm{L} / \mathrm{v}^{\mathrm{sec}}$ & $2 * \delta \mathrm{c}$ & $\stackrel{\text { sec }}{\mathrm{X}}$ & $\mathrm{TI}^{\mathrm{sec}}$ & $\mathrm{T}^{\mathrm{sec}}$ & $\mathrm{T}^{\mathrm{sec}}$ & $\begin{array}{l}\mathrm{sec} \\
\mathrm{TE}\end{array}$ & $\begin{array}{l}\text { deg } \\
\theta c\end{array}$ \\
\hline$\llcorner 50-5$ & 5.926 & 5 & -0.181 & -18.95 & 2.301 & 5.795 & 2.0 & -12.86 \\
\hline$L 50-7.5$ & do. & 7.5 & -0.133 & -16.36 & 2.328 & 5.796 & do. & -15.26 \\
\hline L50-10 & do. & 10 & -0.118 & -15.41 & 2.340 & 5.796 & do. & -16.31 \\
\hline $250-15$ & do. & 15 & -0.077 & -13.40 & 2.387 & 5.835 & do. & -19.05 \\
\hline L100-5 & 11.853 & 5 & -0.093 & -37.88 & 4.546 & 11.459 & do. & -0.81 \\
\hline L100-7.5 & do. & 7.5 & -0.072 & -33.22 & 4. 593 & 11.460 & do. & -2.65 \\
\hline L100-10 & do. & 18 & -0.057 & -30.17 & 4.630 & 11.461 & do. & -4.11 \\
\hline L100-15 & do. & 15 & -0.043 & -27.29 & 4.707 & 11.539 & do. & -5.88 \\
\hline L200-5 & 23.701 & 5 & -0.045 & -75.50 & 9.123 & 22.984 & do. & 6.72 \\
\hline $\mathrm{L} 200-7.5$ & do. & 7.5 & -0.034 & -65.69 & 9.223 & 22.987 & do. & 4.98 \\
\hline L200-10 & do. & 18 & -0.028 & -60.46 & 9.288 & 22.989 & do. & 3.86 \\
\hline L200-15 & do. & 15 & -0.020 & -54.31 & 9.456 & 23.166 & do. & 2.17 \\
\hline L310-5 & 36.778 & 5 & -0.028 & -115.74 & 14.208 & 35.756 & do. & 9.71 \\
\hline$L 310-7.5$ & do. & 7.5 & -0.022 & -103.80 & 14.330 & 35.760 & do. & 8.43 \\
\hline $1310-10$ & do. & 10 & -0.018 & -94.80 & 14.440 & 35.764 & do. & 7.27 \\
\hline L310-15 & do. & 15 & -0.013 & -84.58 & 14.723 & 36.068 & do. & 5.58 \\
\hline
\end{tabular}
$=310 \mathrm{~m}$ で, 針路安定性が違うシリーズの結果を

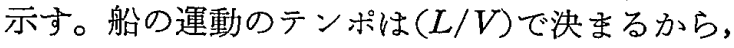
本研究のようにシリーズ船の速力を一定之する と, 船の長さが直接その船のテンポの違いを示す ことになる。この結果から，針路不安定な船の周 波数応答特性を特徵づけるのはその位相特性であ ると指摘できる。この位相特性は和よそ次のよう に説明できる。針路不安定な船では低周波数域で は，位相遅れが大きく，3 $3 \pi / 2$ となる。周波数が高
表 2 供試シリーズモデルの操縦性指数 


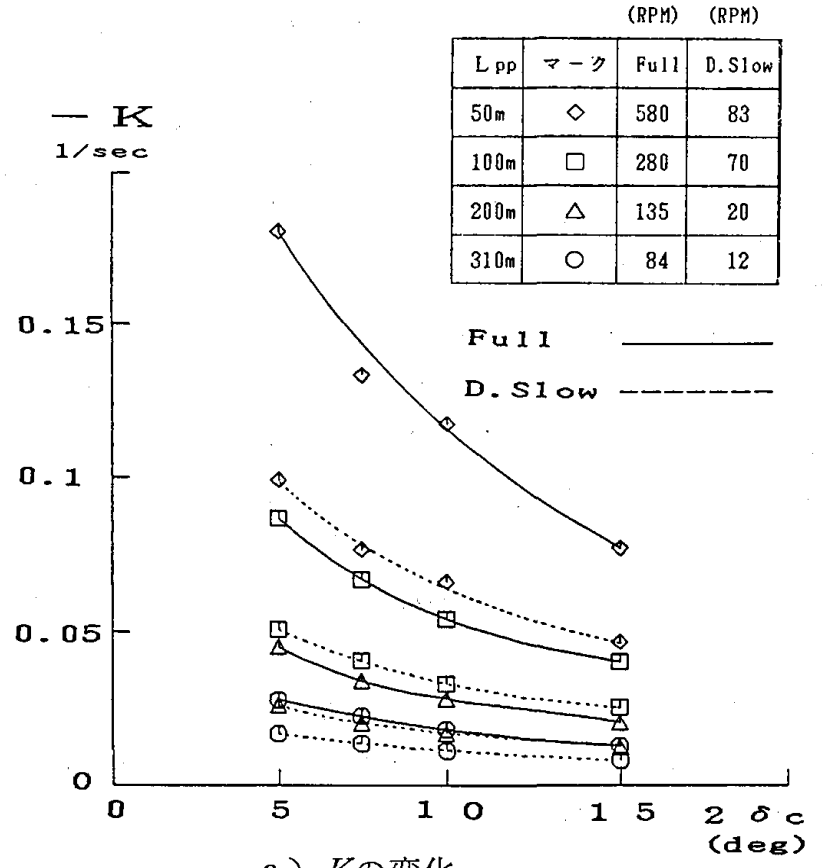

a ) Kの変化

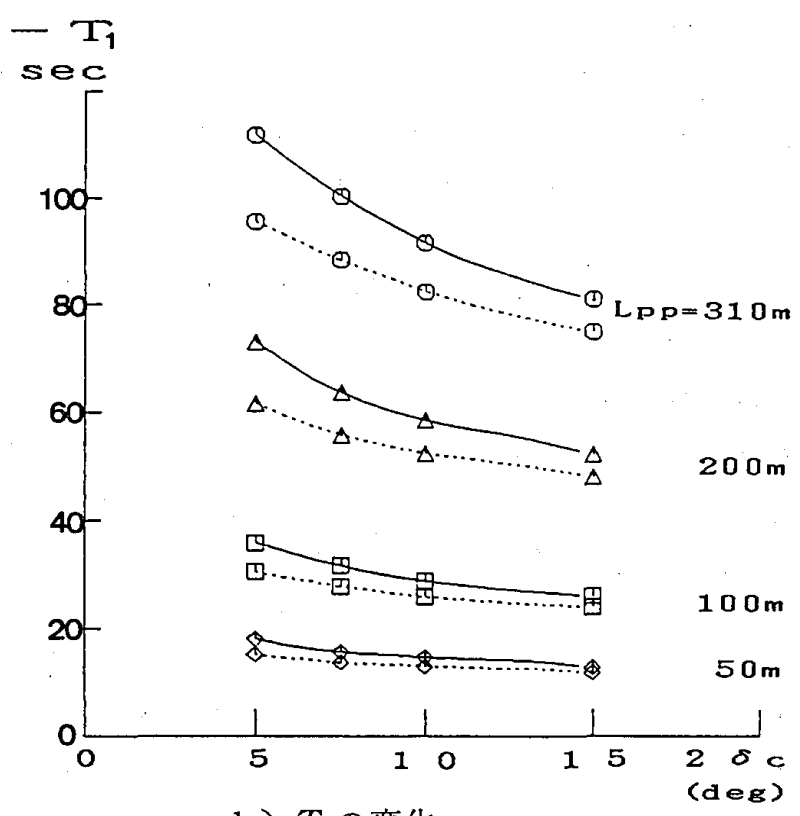

b) $T_{1}$ の変化

図 2 船長，針路安定性の違いによる操縱性指数の变化

くなるにつれて，T3 の位相進み效果が増してきて， 位相遅れは $\pi$ 以内に回復する。更に周波数が高くな ると， $T_{2}$ が位相を遅らす方向に效いてくるので, 船自体の位相遅れは最終的に $\pi$ になる。

制御対象全体としては, これに操舵機の特性が加 わる。操舵機の時定数 $T_{E}$ は船の大きさによらずほ ぼ一定であるから, 小型船, 高速船では $T_{3}$ と $T_{E}$ の比が小さくなる。この為, $T_{3}$ の位相進め効果が 十分に現れないららに $T_{E}$ による䐅れが発生し, 中 間周波数域に和ける位相遅れの大きさを大きく支配

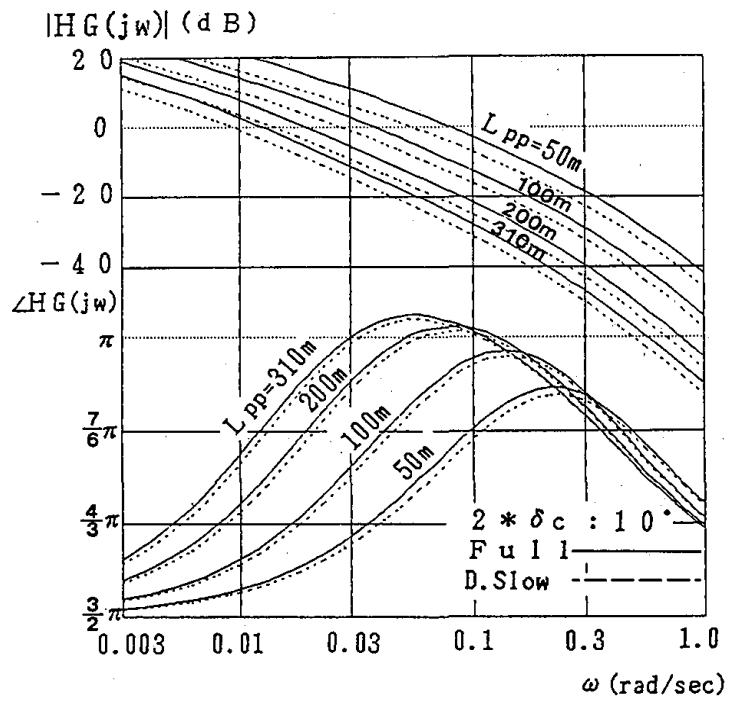

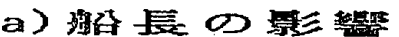

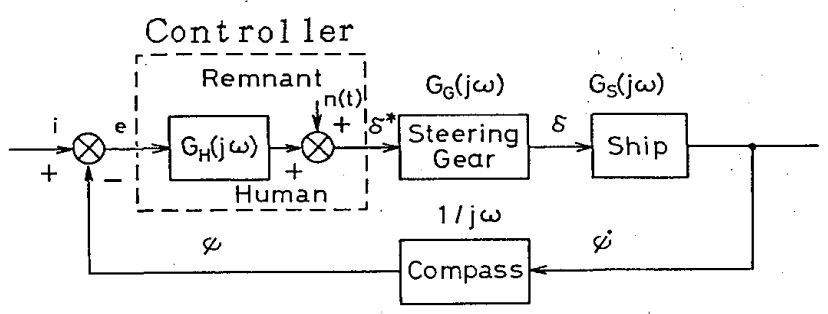

図 3 人間の制御特性モデル （文献（9）から引用）

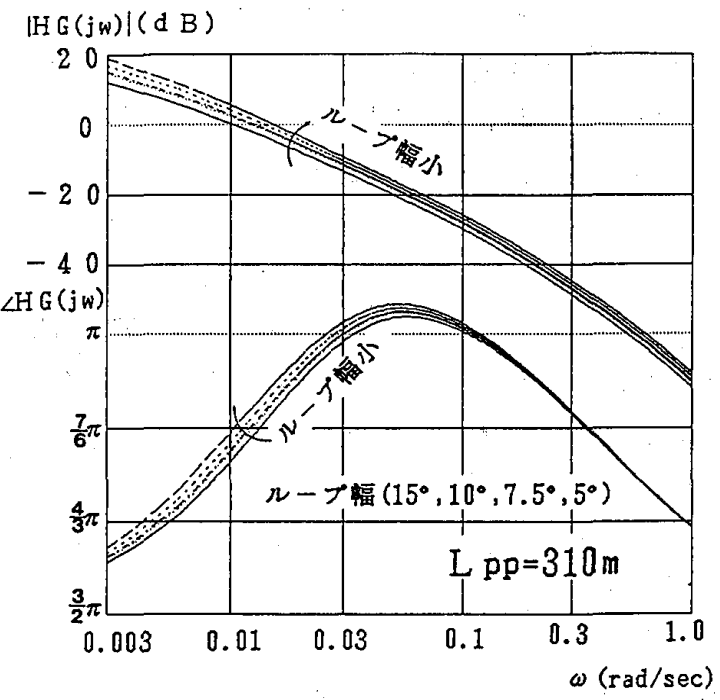

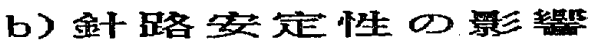

図 4 供試シリーズモデルのゲイン，位相特性 
することになる。図 4(a)中の実線で示す特性は, 船長, ひいては船の運動のテンポがちがった場合の位相特性 の変化を典型的に示すものである。

さて，制御対象の周波数特性に船の針路安定性がぞのように効くかが，図 4(b)からわかる。この針路安定性 のちがうモデルは，舵面積を増減する形で導いたものであり，安定性のよい船は舵面積を増した分だけゲインが 大きくなっているが，その程度は小さいことがわかる。位相特性については，ループ幅が $5^{\circ}$ から $15^{\circ}$ とら相当 に針路安定性がちがうモデルであるにもかかわらず，予想以上に位相特性の変化が小さいと指摘できる。これは 中間周波数域に护将る位相特性が $T_{2}, T_{3}$ に規定されるが，この 2 つの時定数は舵面積が変化した程度では殆ぞ その值を変えないからである。ここで，舵面積が操綐性指数に及ぼす影響について多少の考察を加えて扣く。舵 面積を変化させた時，主として変化する微係数は $Y_{o}, N_{\delta}$ である。 $Y_{r}, N_{r}, Y_{v}, N_{v}$ の項は乞の主力は主船体で 決まり，舵の寄与する部分はわずかであるが，操縦性には大きく效いてくる。又，船の質量や付加質量の項に至 っては殆ど影響がないと考えてよい。このことを考慮すると，舵面積の影響が大きいのは，まず $q_{3}\left(=Y_{v}{ }^{\prime} N_{r}{ }^{\prime}+\right.$ $\left.N_{v}{ }^{\prime}\left(\left(m^{\prime}+m_{x}{ }^{\prime}\right)-Y_{r}{ }^{\prime}\right\}\right)$ であり，第 1 項と第 2 項は肥大船ではきわどいバランスを保っている。それで，この $q_{3}$ は零付近の值をとり，微係数のわずかなちがいで正負に值を転じる。したがって，この $q_{3}$ が效いてくる $T_{1}$ は大 きく影響を受けるが $T_{2}$ はあまり変化しない。又， $Y_{\delta}, N_{\delta}$ は舵面積の変化によって，注同じ割合で増減するか ら $T_{3}$ の分子と分母の増減は互いに相殺されて， $T_{3}$ は殆ど变わらないといら結果になる。な拉，本研究の供試船 は表 2 に示した舵面積を变更した場合について成り立つものである。船型要目が大幅に变化した時に，これらの 操繸性指数がどのように变わるかについては，別の機会に諭じたい。

さて，制御対象の特性がわかったので，制御系全体の性能の㭘討に移る。制御系の性能を把握する際の基本は， その安定性である。これには，ナイキストの安定判別の方法(6)があり，それによると、コントローラと制御対象 を併せた一巡伝達関数を求め, そのゲインが 1 となる周波数，カットオフ周波数に和いて，その位相遅れが $\pi$ 以 内であれば，制御系は安定になることがわかる。

前述の制御対象の応答特性を考皇ると，もし可能ならば，コントローラのゲインを調整して，カットオフ周波 数を制御対象の位相遅れが最少となる周波数域に一致させることがでされば，少ない位相進みで制御系の安定性 が保らうることになる。人間であれ，オートパイロットであれ，パワーステアリングが採用されている現在の船 にあっては，このゲイン調整は極めて容易であるから，上記の最少となる位相遅れの值，つまり安定性から必要 とされる位相補償量が制御系の性能を決めることになる。表 2 に本供試船の位相補償量を示す。

2. 3 減速中の船の保針制御特性

減速中には時々刻々と船の性能が変わり，それに応じてコントローラも特性を変えている。しかし，減速中に 抢ける船速の追従は，旋回応答に比べて極めて緩やかであるから，この過渡状態に拉ける船の保針性能の基本は， その時の船速とプロペラ回転数によって決まると考光ることができる。つまり，減速中の保針をその時々の船速 とプロペラ回転数で決まる準定常問題として取扱らという視点をうる。そこで, 減速中に生じる船速とプロぺラ 回転下における船の旋回応答特性について検討を加えた。図 2 中に各船の Full, D. Slow に対応するプロペラ 回転数をしめす。又，同図の破線がプロペラ回転数が Full に対応する船速で航行中に D. Slowを指令した場合 の $K, T_{1}$ の変化を示したものである。むず，スタティックダインにあたる $K$ は, プロペラ回転数の減少に応じ て顕著に下がり，Full の場合に比べて D. Slow は約 1/2 程度になる。T で示される安定性もやはり回転数の減 少により悪化するが，Kほどではない。又， $T_{2} ， T_{3}$ については，ほとんど回転数による変化はない。この操縱 性指数の変化の仕方は, 先述の舵面積の増減の場合と同じ議論で説明できるものである。図 4 ( a)中の破線は, 減速により変化した指数を用いて描いた操舵指令に対する旋回応答のゲインと位相荤れる計算したものである。 ゲイン特性の方は舵効きが低下した分だけ，小さくなり，位相の僬れも大きくなっている。しかし，ゲインが

Full 時に比べ約 $1 / 2$ に減少しているのに対し, 位相の変化はわずかであり, 安定化に必要とされる位相補償量 には顕著な差はない。

\section{3. 操舵貣による減速中の保針限界}

減速中の保針制御系は，操舵する人間の立場から考えると，制御対象の性質が船速の变化に伴って時々刻々と 変わることになる。しかし，この船速変化は極めて緩やかであるから，人間は相当程度制御対象の性能变化に追 
従して，自らの制御特性を調整できると考えられる。この立場から，制御対象の性能は船速とプロペラ回転数で 決まり，その性能に十分にチューニングされた人間の特性を組合わせる形で減速中の保針制御の基本的性質が解 明できると考㝋る。

これらの考え方を笑証するためには，減速状態を操船シミュレータに設定し，操舵員による保針のシミュレー ションを試みるのが有益と考えられる。

そこで，昨年度に開発した操船シミュレータ(7)を用いて，減速中の保針操船に関するシミュレーションスタデ ィを試みた。このシミュレーションスタディの供試船は前述の16種のシリーズモデルである。

3. 1 人間のモデルと加える外乱

人間の制御動作は非定常性，非線型性等を含み相当複雑なものであるが，平均として把握された線型部分 $H(j \omega)$ で基本が表現できるものとし，それ以外の成分をレムナント $n(t)$ といういわば人間の発生したノイ ズと考觉る(8)。こうすると，人間を含さ制御系の特性の基本はこの線型成分で議論できると期待される。この考 えの下で，船の保針制御系は図 3 のように表現できる。この図中の $i(t)$ は船が受ける外力であり，コントロー ラはこの外力の影響をキャンセルし，船の針路誤差が零になるように制御出力，つをり指令舵角を与える。この 場合の人間の平均的な周波数特性は，この外乱に対する人間の応答と結果のそれぞれのクロススペクトル密度の 比である次式で表現できる。このことは，文献(9) に詳しい。

$$
Y_{h}(j \omega)=\frac{\phi_{i \delta}^{*}(j \omega)}{\phi_{i \phi}(j \omega)}
$$

$\dot{\psi}_{\mathrm{N}}$

$\phi_{i_{\delta}}{ }^{*}$ : 角速度相当の外乱と命令舵角とのク口 ススペクトル密度

$\phi i \phi$ : 角速度相当の外乱と針路誤差とのクロス スペクトル密度

本研究では, 正横方向からの平均風速 $10 \mathrm{~m} / \mathrm{s}$ でそとのスペクトルがダーベンポートによるとし た場合の変動風と出合い周期 5 秒の波浪によって 生じた外乱を加えた。船長が $100 \mathrm{~m}$ の場合に加党 た回頭角速度の形に換算した外乱のパワースペク トル密度の例を図 5 に示す。それぞれ低周波域が 変動風の，高周波域が波浪の成分であるが，波浪 の成分については繁雑さを避けて同一船長のもの は同一の波浪応答とした。

3. 2 人間の制御特性と限界

まず，通常船速で保針操舵を行った結果から前 述の方法で求めた人間の制御特性の例を図 6 に示 す。小山等の結論 ${ }^{(9)} の$ と扣り，人間が与えうる位
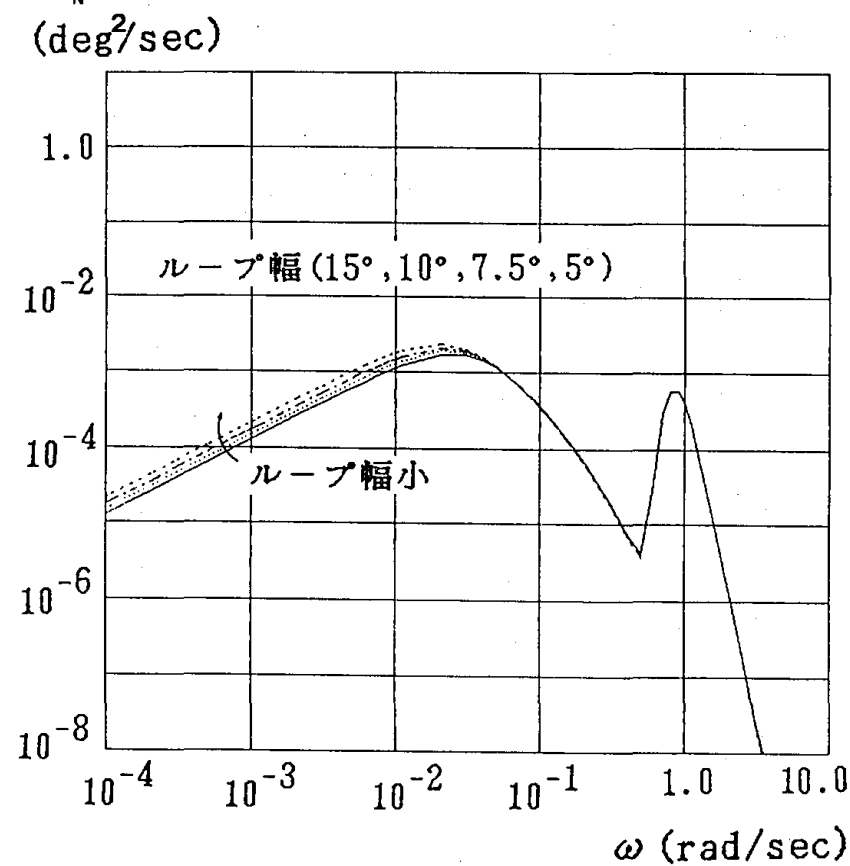

図 5 保針時に付加した外乱のパワースペクトラム $(\mathrm{L} p \mathrm{pp}=100$ シリーズ) 相補償量は，一般に $\pi / 6$ 程度から $\pi / 3$ 位のようで ある。又, 図 7 の実線は船と操舵機の応答特性であり，実験点は人間を含んだ一巡伝達関数を示している。人間 の制御のゲインは，でたらめに設定しているわけではなく，位相遅れが小さくなる周波数域にカットオフ周波数 を設定するように調整されていることる確諗できる。

また，減速中に生じる船速とプロペラ回転数で決まる船の性能をセットして，保針シミュレーションを行った。 こうした状態の船の性能に対しても人間の制御特性は上述の指摘のと和りであることを確認した。

したがって，減速中の人間による保針を考えた場合，制御対象の変化に追従して，人間がどの程度すみやかに， 自己の特性を調整できるかが問われることになる。この人間の特性のチューニング能力をチェックするために， しばらく一定速力で航行後，プロペラ回転数を極端に減らし，減速しつつ保針するというシミョレーションを行 


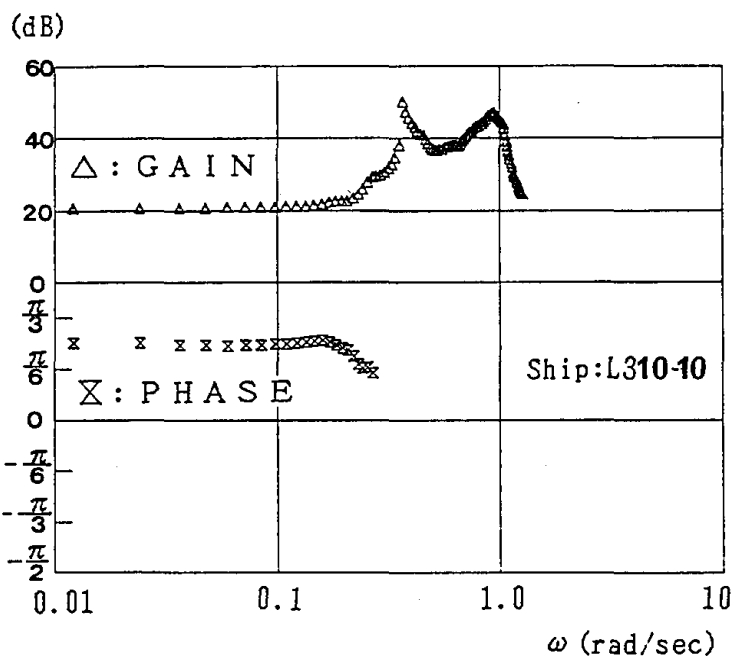

(a)

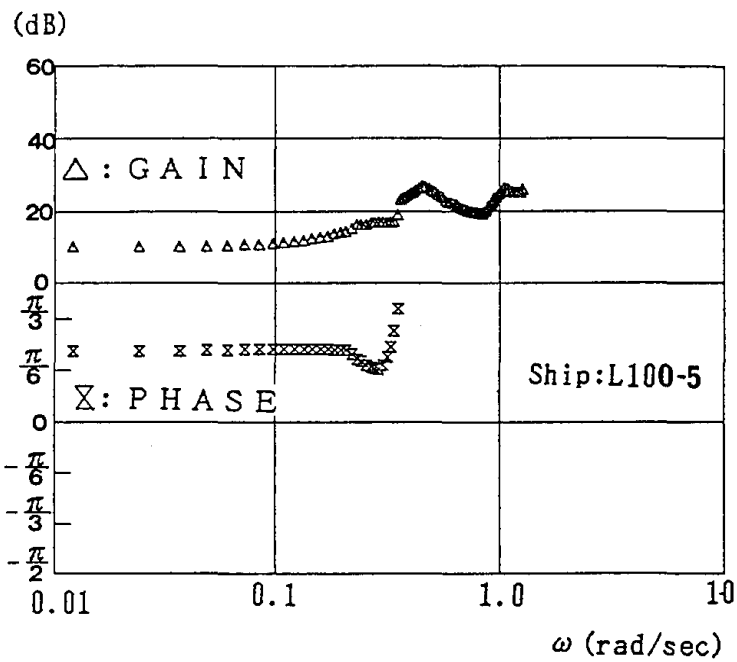

(b)

図 6 針路不安定船の保針時に特ける人間の特性の同定例

(d B)

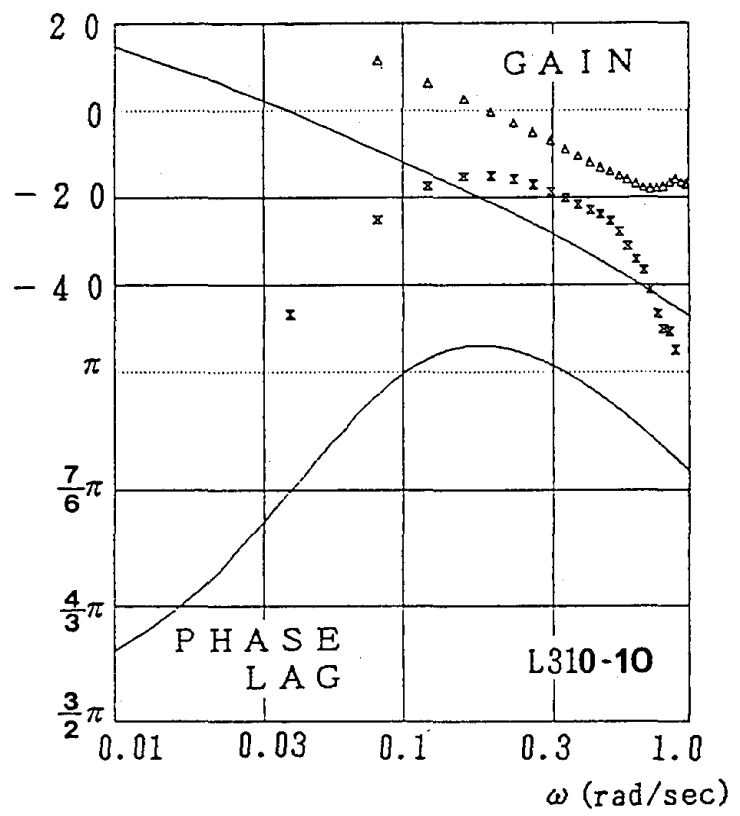

(a) (d B )

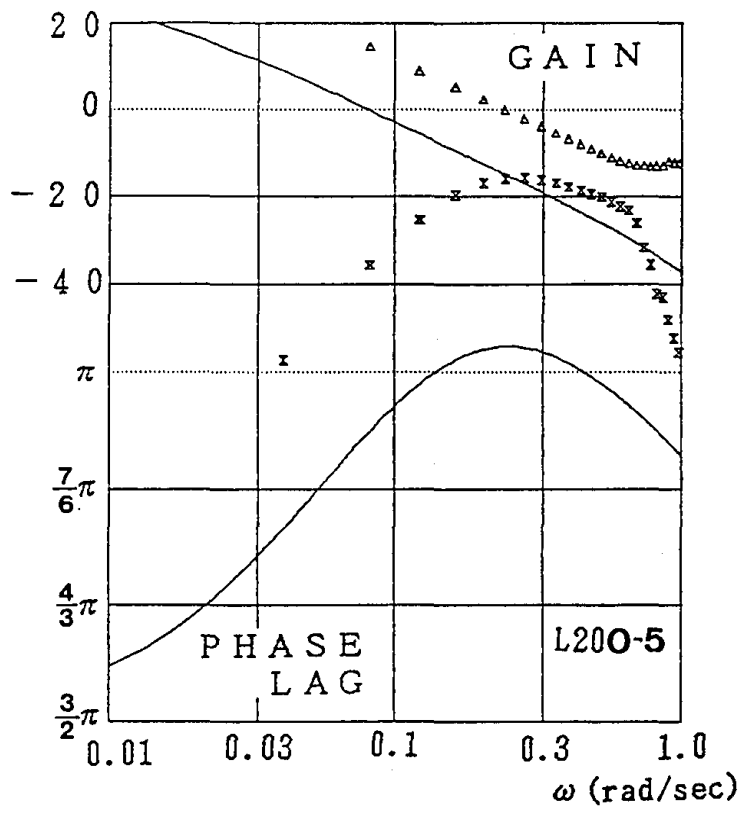

(b)

図 7 人間による保針時の制御系の応答特性の例

った。その時の船速, 方位, 舵角の時系列を図 8 に示す。プロペラ回転数を減じた直後, 船の特性が急速に変わ ったことになり，しかも最も針路不安定になっているのであるから，もし人間の制御特性のチニーニングがうま くいかないのであれば，安定性に問題を生じ，蛇航が増すはずである。しかし，減速開始から図 8 のB点付近ま では特に顥著な蛇航の増加は見られないから，およそ人間はすみやかに自己の特性をチニーニングしているもの と考えられる。

このことは制御対象の特性から考えて，ゲインのチューニングはかなり大杂倠把でよいと判断されるところから 十分に予想できるものである。つまり，位相遅れが最少になる範团は緩やかな山状の特性になって和り，カット オフ周波数が多少どちらかにずれても，極端な位相補償量の增加は生じないからである。

減速が進むにしたがって船の安定性は少しずつ回復するけれども，外力の影響は相対的に大さくなる。そこで， 外力の影響による蛇航は船速の低下とともに顕著になり，最終的には操舵によって外力に抗する旋回モ一メント 


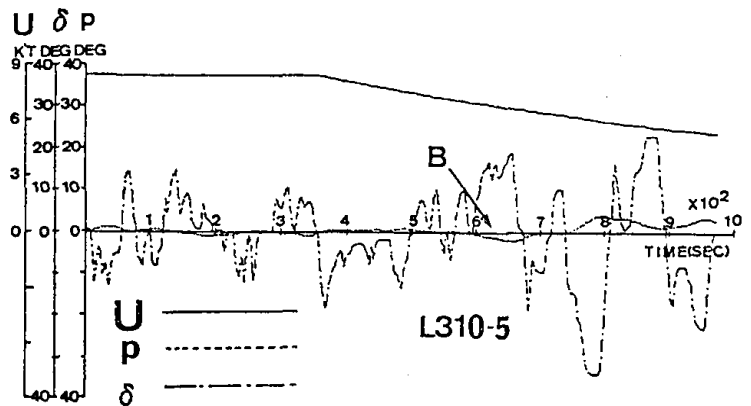

(a)

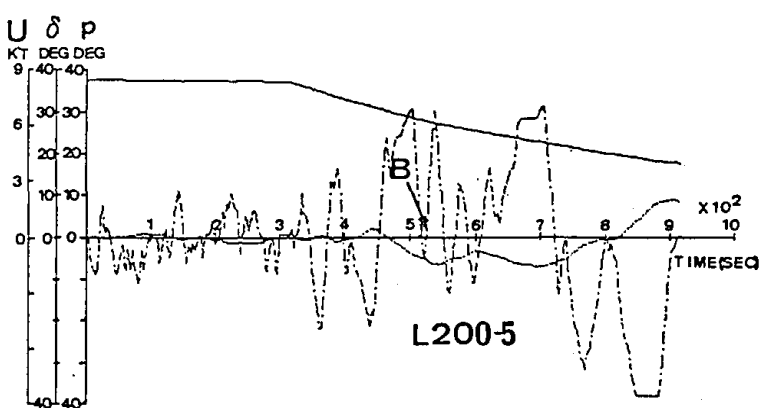

(b)

図 8 減速時の保針シミュレーション例

が確保できなくなって，ついには針路の発散を招くことになる。その外力との静的な釣合い限界と思われる点が 図 8 のB点である。この釣合問題については, すでに多くの船型に対して計算例(10) が示されているのでここで は論じない。

ここでの結諭は，動的な意味での人間による保針，換言すると，人間の操縦下に括看保針制御系の安定性は， 一定速力で航行中と較べて減速中にむ極端な低下はないと見込まれることである。したがって，チューニング漏 れ等を考慮して，一定船速航行時の保針制御系をある程度余裕を持って評価しておけげ，静的な釣合いの十分に 保ちらる範囲ならば，減速中も動的な意味での安定性が保たれると考兄てよいと指摘できる。

\section{4. 結言}

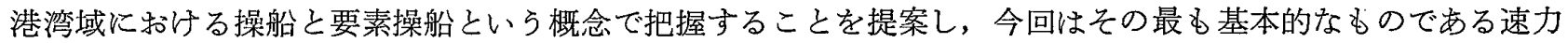
変更を含む保針について人間による針路不安定船の減速中の保針がどこまで可能かという問題を中心に検討を加 えた。得られた主な結論は次のと和りである。

(1) 一定速力航行中之同様, その時々の船速とプロペラ回転数で決まる船体の応答特性に操舵機の特性を加党 た周波数応答から決まる位相補償必要量が減速時においても人間による保針の可能性の目安になる。

（2）一定速力航行時に較べて減速中船のゲインはかなり低下するが，位相の遅れの増加はわずかである。

（3）人間による保針は，制御対象の位相遅れが最少になる周波数域に，一巡伝達関数のゲインが 1 となる周波 数を設定するように自らゲイン特性を調整し，位相補償量が最小ですむように制御している。その限界は， $\pi / 6$ $\sim \pi / 3$ 程度であり, 保針制御の限界を規定する。

（4）人間に上る保針制御系の安定は，減速中にも極端な低下はない。一定船速航行時の保針制御系をある程度 余裕を持って評価して和讬ば，減速中も安定性が保たれる。この研究の一部は，文部省科学研究費補助金を用い た成果であることを付記する。又, この研究の過程で, 操船の専門家として協力いただいた弓削商船高専の地本 船長, 豊田一等航海士, 大島商船高専の西田船長に御礼を申し上げたい。又, 日本造船研究協会 RR 742 分科会 （小山健夫主查）に和ける種々の討論は本研究の進展に有力な手がかりを与兄るものであった。最後に, 広島大 学工学部の浮体運動学研究室の諸氏のご協力も忘れることがでさない。付言して謝す次第である。

\section{参考 文 献}

（1） 日本造船研究協会第 7 基準研究部会：国際規則と船舶設計等との関連に関する調査研究報告書（別冊）一 船船の操鏦性に関する研究一, 昭和59年 3 月

（2）例えば柏木正：不均一潮流中での船舶操縱運動の計算法と鳴門海峡に持ける適用例，日本航海学会論文集, 第75号, pp. 55 67, 昭和61年

（3）例兄ば小瀬, 日當, 橋詰, 二川：低速で航行する船の操縱運動モデルについて, 日本造船学会論文集, 第 155 号, 1984

（4）小瀬, 日當: 出入港時の要素操船性能について一I. 一出入港操船と要素操船性能一, 日本航海学会論文 
集, 第74号, pp. 29〜34, 昭和61年 3 月

（5）小瀬, 湯室, 芳村 : 操縦運動の数学モデルの具現化一船体・プロペラ・舵の相互干渉とその表現, 日本造 船学会, 第 3 回操縦性シンポジウム, pp. 27〜 52 , 昭和 62 年 12 月

（6）伊沢計介：自動制御入門，オーム社

（7），小瀬，平田，平尾，大橋，浜田：出入港操船シミュレータ，日本航海学会論文集，第79号，pp. 101～107， 昭和63年

（8）後藤：手動制御系に和ける操縦者の線型モデルについて，日本航空学会誌，21巻232号，昭和48年

（9）小山，小瀬，長谷川：保針操舵に打ける針路不安定の許容限界に関する考察，日本造船学会論文集，第 142 号, pp. 119 126, 昭和52年

（10）小林，中谷：定常風下に括ける保針操舵限界に関する一考察，日本航海学会論文集，第66号，1981

\section{質 疑 応 答}

烏野慶一：人間の特性について，微分特性，積分特性が存在すると思いますが，この場合どちらが現れているの でしょらか。

岩崎寛希：人間の特性は，微分特性に現れ，積分特性はあまり発揮できないと言われています。しかし，今回は 人間の特性を仕分けして解析はしておらず，位相補償量，ゲイン調整等を人間の総合的な特性として算出いた しました。

奥村宗行：前刷りの図 1 と講演時 OHP の図と違って見えますが，特に PHASE LAG の曲線で見えますが，ぞ うしてでしょらか。

又, 超大型から小型船に向ってカーブのピークが右にずれていくのはどらいう理由か示して下さい。船丈と その舵面積比についての影響があるのか，その影響をどのように取扱っているのでしょうか。

岩崎寛希：前刷りの図 1 とOHP は同じ図ですが，位相遅れのスケールが違いました。誤解を招きましたことを 深くま詫びいたします。

小瀬邦治：問題の図 4 は，人間の制御の対象となります船体，操舵機，コンパスの系の周波数特性を描いたもの です。船体のみの特性に限定しますと，針路安定な船と違い，不安定船の場合は位相遅れは低周波域で $1.5 \pi$ となり，高周波になるにつれて，一度は $\pi$ 以内に回復し，最終的には $\pi$ に落ちつきすす。これに，今回各船ル ール等を考慮して操舵機の時定数は一律に 2 秒としましたが，この操舵機の一時遅㞦が加わると，位相遅れの $\pi$ への修復するか否かは，各船の運動のテンポを表す $T_{3}$ によって左右されることになります。小型船程 $T_{3}$ と $T_{E}$ の比が小さくなるため， $T_{3}$ の位相進め効果が十分効かないうちに $T_{E}$ の遅れが発生し，位相遅れが $\pi$ に回復していません。したがって，グラフが小型船程右にずれるのは運動のテンポが速くなるためで，又，ピ 一ク值が下がるのはその右にずれる位相に対し，操舵機の時定数が高周波数域で一律に位相を遅らせるように 効いてくるためです。 